\title{
The Comparison Between the Judicial Commission of the Republic of Indonesia and the Netherlands Council for the Judiciary
}

\author{
Suparto \\ Faculty of Law, Universitas Islam Riau, Pekanbaru, 28284, Indonesia. \\ E-mail: suparto@law.uir.ac.id
}

How to cite : Suparto. (2019). The Comparsion Between the Judicial Commission of the Republik of Indonesia and the Netherlands Council for the Judiciary. UNIFIKASI : Jurnal IImu Hukum, 6(1), 40-52. DOI : 10.25134/unifikasi.v6i1.1527

Submitted : 07-12-2018 Revised : 31-05-2019 Accepted : 10-06-2019

\begin{abstract}
The purpose of this study is to analyze the position and authority of the Judicial Commission of the Republic of Indonesia and its comparison to the Netherlands Council for the Judiciary. This comparative study applied a normative juridical method. The data used in this study were secondary data. The collected data were then analyzed qualitatively. The results showed that Judicial Commission has an important position in judicial system in Indonesia so as structurally, its position is aligned with the Supreme Court and the Constitutional Court of the Republic of Indonesia. Yet, functionally, its role is auxiliary to the judicial power institutions. Although the function of the Judicial Commission is related to judicial power, but the Judicial Commission is not an agent of judicial power, rather, it is an agency enforcing code of ethics of judges. Besides, the Judicial Commission is also not involved in the organization, personnel, administration and financial matters of judges. This condition is different from the Judicial Commission in European countries, such as the Netherlands. The Judicial Commission in the Netherlands (The Netherlands Council for the Judiciary) has an authority in the area of technical policy and policy making in the field of justice. The Netherlands Council for the Judiciary and other Judicial Commission in European countries generally have the authority in managing organization, budget and administration as well as in conducting promotions, transfers, and recruitments as well as imposing sanctions on judges. Thus, the Supreme Court only focuses on carrying out judicial functions and does not deal with administrative and judicial organization matters.
\end{abstract}

Keywords: Comparison; the Judicial Commission of the Republic of Indonesia; the Netherlands Council for the Judiciary.

\section{Perbandingan Komisi Yudisial Republik Indonesia dan Komisi Yudisial Belanda}

\begin{abstract}
Abstrak : Tujuan dari penelitian ini adalah untuk mengetahui dan memahami tentang kedudukan dan kewenangan Komisi Yudisial Republik Indonesia serta perbandingannya dengan Komisi Yudisial Belanda. Metode penelitian yang digunakan yaitu yuridis normatif dengan cara perbandingan (komparatif). Data yang digunakan adalah data sekunder sedangkan analisis data dilakukan secara kualitatif. Hasil penelitian yaitu bahwa kedudukan Komisi Yudisial sangat penting, sehinggasecara struktural kedudukannya diposisikan sederajat dengan Mahkamah Agung dan Mahkamah Konstitusi. Namun demikian secara fungsionalperannya bersifat penunjang (auxiliary) terhadap lembaga kekuasaan kehakiman. Komisi Yudisial meskipun fungsinya terkait dengan kekuasaan kehakiman tetapi bukan pelaku kekuasaan kehakiman, melainkan lembaga penegak norma etik (code of ethics) dari hakim. Selain itu Komisi Yudisial juga tidak terlibat dalam hal organisasi, personalia, administrasi dan keuangan para hakim. Hal ini berbeda dengan Komisi Yudisial yang ada di negara Eropa misalnya Belanda. Komisi Yudisial di Belanda (Netherland Council for Judiciary) memiliki kewenangan pada area kebijakan teknis dan pembuatan kebijakan pada bidang peradilan.Komisi Yudisial Belanda dan di Eropa pada umumnya mempunyai kewenangan dalam hal mengelola organisasi, anggaran dan administrasi peradilan termasuk dalam melakukan promosi, mutasi, rekruitmen dan memberikan sanksi terhadap hakim. Mahkamah Agung hanya fokus melaksanakan fungsi peradilan yaitu mengadili dan tidak mengurusi masalah administrasi dan organisasi peradilan.
\end{abstract}

Kata Kunci: Perbandingan; Komisi Yudisial Indonesia, Komisi Yudisial Belanda.

\section{INTRODUCTION}

Two state institutions, namely the Constitutional Court and the Judicial Commission, are established after the amendment of the 1945 Constitution in the field of judicial power. This establishment aims to enhance the role of the judicial power institutions in Indonesia. As result, 
relations between state powers are shifted. Executive power carried out by the President, legislative power carried out by the House of Representatives of the Republic of Indonesia, and judicial power carried out by the Supreme Court and the Constitutional Court of the Republic of Indonesia are an embodiment of checks and balances system. ${ }^{1}$ Amandement of the legislations in the field of judiciary is one of the steps that needs to be taken to rebuild judicial institutions in Indonesia. The problems surrounding the judiciary cannot be handled due to the weaknesses of various regulations which have failed in creating a system that is conducive to build an independent, impartial, clean, competent and efficient court. Another important effort to synergize judiciary reform in Indonesia is the establishment of an institution called Judicial Commission as regulated in Article 24B of the Third Amendment of the 1945 Constitution and Law No. 18 of 2011 concerning Amendment to Law No. 22 of 2004 concerning Judicial Commission. The establishment of Judicial Commission is a logical consequence arising from the merging of the judiciary in the Supreme Court. It turns out that the merging has the potential to cause a monopoly on judicial power by the Supreme Court. In addition, there is a concern that the Supreme Court will not be able to carry out administrative, personnel, financial and court organization authority which has been carried out by the Department of Law and Human Rights all the time. There is even a pessimistic view that the Supreme Court cannot carry out the given authority properly. ${ }^{2}$ Therefore, it is considered necessary to have an institution outside the Supreme Court that can supervise the judges' behavior within the Supreme Court. In this case, the Judicial Commission is a state institution that has the authority to supervise the behavior of judges, supreme justices, and constitutional judges in which its position is outside the scope of judicial power in order to maintain the judges' integrity. ${ }^{3}$

A study conducted by A. Ahsin Thohari concluded that the main reasons for the emergence of the idea of establishing a Judicial Commission in various countries are:

(1) A weak monitoring against judicial power as monitoring is only carried out internally.

(2) There is no institution serving as a liaison between government authorities, in this case the Department of Justice, and judicial power.

(3) Judicial power is considered not to have sufficient efficiency and effectiveness in carrying out its duties if it is still preoccupied with non-legal technical issues.

(4) A low quality and lack consistency of judicial institutions decisions since they are not intensively monitored by independent institutions, and

(5) Judicial recruitment pattern is too biased with political issues since the institutions that propose and recruit them are political institutions, namely the president or parliament. ${ }^{4}$

In Indonesia, the position of the Judicial Commission is determined by the 1945 Constitution as a separate State institution because its role is considered very important in an effort to safeguard and uphold the honor, the high status and the behavior of judges. If judges are respected for their integrity and quality, the rule of law can then be enforced as it should be. The enforcement of rule of law is actually a prerequisite for the growth and soundness of a democratic system that is to be built according to the constitutional system of the 1945 Constitution. Democracy is impossible to grow and develop, if the rule of law is not upheld by its honor, authority, and trustworthiness. Due to the importance of efforts to safeguard and uphold the honor, the high status and the behavior of judges, a separate

\footnotetext{
1 Abustan. "Relasi Lembaga Negara dalam Perspektif Undang-Undang Dasar Negara Republik Indonesia 1945”, Jurnal Unifikasi, Vol. 4, No. 2, Juli 2017, p.59.

2 Sirajuddin dan Zulkarnain, 2006, Komisi Yudisial Dan Eksaminasi Publik, Bandung : Citra Aditya Bakti, p. 70-71.

3 Erniyanti. “Eksistensi Kewenangan Komisi Yudisial dalam Pengawasan Hakim Menurut Undang-Undang Dasar Negara Republik Indonesia Tahun 1945", Jurnal Samudra Keadilan, Vol. 10, No.2, 2015, p. 242.

4 A. Ahsin Thohari, 2004, Komisi Yudisial dan Reformasi Peradilan, Jakarta : Lembaga Studi dan Advokasi Masyarakat (ELSAM), p. 31.
} 
independent institution needs to be established so that supervision can be carried out effectively. The internal supervision system, as it has been done so far, namely the presence of honorary judges, has not proven effective in conducting supervision. Therefore, in the amandement of the 1945 Constitution, a separate institution called the Judicial Commission was established. ${ }^{5}$ Weak internal supervision institutions are influenced by several factors, namely inadequate quality and integrity, intransparent disciplined inspection processes, lack of easiness for the public to complain and monitor the process and results of their complaints, a strong spirit of defending corps, and unwillingness of the institution's leaders. ${ }^{6}$

Further, the existence of new institution that will monitor judges' behavior in the constitutional system of the Republic of Indonesia is regulated in the 1945 Constitution. With the existence of Judicial Commission as a state auxiliary organ against judicial power institutions, it is expected that the ethical behavior system in all sectors both superstructure and infrastructure of the state can be developed accordingly in order to realize the rule of law and the principles of good governance in all fields. ${ }^{7}$ In carrying out its authorities and duties, there have been many positive things done by the Judicial Commission, especially in conducting selection of candidates for supreme justices. Yet, in terms of protecting the honor of judges from disgraceful acts and unprofessional conduct, the role of the Judicial Commission has not been optimal. Besides, there are still many recommendations proposed by the Judicial Commission related to judges are ignored by the Supreme Court. ${ }^{8}$

In contrast, one of the reasons of the establishment of the Judicial Commission in European countries is to revive public trust against judiciary. Many reasons and motives exist to establish Judicial Commission in European countries. Yet, in some European countries, Judicial Commission is established with the aim of developing and realizing efficient judiciary. The main roles of Judicial Commission in Europe are; 1) ensuring the independence of judiciary; 2) proposing candidates for judges, providing quality education for judges, and performing other functions, such as enforcing judicial discipline, selecting judges, providing professional education for judges, testing judges' competences, and enforcing code of ethics of judges; and 3) taking over the judicial management function from the government (executive). Those are the roles of Judicial Commission in European countries, especially in Northern Europe, such as the Netherlands. ${ }^{9}$ Based on this description, this study tries to analyze the position and authority of the Judicial Commission of the Republic of Indonesia compared to the Netherlands Council for the Judiciary.

\section{RESEARCH METHODS}

This comparative study applied a normative legal method. The data used were secondary data, namely the 1945 Constitution of the Republic of Indonesia, Law No. 22 of 2004 concerning Judicial Commission, Law No. 18 of 2011 concerning Amendment to Law No. 22 of 2004 concerning Judicial Commission, the Dutch Constitution (Ground Wet), research results, journals, books, and legislations. The collected data were then analyzed qualitatively. The stages of data analysis included; 1) data

5 Jimly Asshiddiqie, 2005,Perkembangan dan Konsolidasi Lembaga Negara Pasca Reformasi, Jakarta : Konpress MKRI, p. 187-188. Lihat juga Titik Triwulan Tutik, 2007, Eksistensi, Kedudukan dan Wewenang Komisi Yudisial ; Sebagai Lembaga Negara Dalam Sistem Ketatanegaraan RI Pasca Amandemen UUD 1945, Jakarta : Prestasi Pustaka Publisher, p. 78-84. Nurhayati, Nunik. " Eksistensi Kewenangan Komisi Yudisial Republik Indonesia dalam Undang-Undang Dasar Republik Indonesia 1945”, Jurnal Law and Justice, Vol. I, No. 1, 2016, p.12.

Jimly Asshiddiqie, Loc. Cit., p. 188.

Sutiyoso, Bambang. " Penguatan Peran Komisi Yudisial dalam Penegakan Hukum di Indonesia”, Jurnal IusQuia IusTum, Vol. 18, No. 2, 2011, p.268.

$9 \quad$ Wim Voermans, "Indonesia Councils for Judiciary, Seminar of Comparative Models of Judicial Commissions" Makalah dalam Seminar Peran Komisi Yudisial Di Era Transisi Menuju Demokrasi, Komisi Yudisial RI, 5 Juli 2004, Jakarta. 
collection, 2) data selection and classification which were done systematically and logically to find out the specific picture related to the problem discussed, 3) data interpretation, and 4) data comparison with theories and concepts from the secondary data used.

\section{RESULTS AND DISCUSSION}

\section{A. The Judicial Commission of the Republic of Indonesia \\ 1. Position, Organization and Membership}

Judicial Commission has an important position in judicial system in Indonesia so as structurally, its position is aligned with the Supreme Court and the Constitutional Court of the Republic of Indonesia. However, it should be noted that, although structurally its position is aligned with the Supreme Court and the Constitutional Court of the Republic of Indonesia, but functionally, its role is auxiliary to the judicial power institutions. Although the function of Judicial Commission is related to judicial power, but Judicial Commission is not an agent of judicial power. The Judicial Commission is not a code of law enforcement agency, but a code of ethics enforcement agency because this commission only deals with the honor, the high status and the behavior of judges, not with judicial institutions or judicial power institutions. Its existence is actually derived from the internal environment, namely from the conception of honorary judges existing in judicial profession and within the Supreme Court. It means that this ethical auditor function was internal. However, to better guarantee the effectiveness of its authority in order to supervise the behavior of judges, the function is shifted to be an external auditor in which its position is aligned with the supervisor. ${ }^{10}$

Although structurally its position is aligned with the Supreme Court and the Constitutional Court, but due to its nature as an auxiliary to the judicial power institutions so that its protocol position does not need to be treated the same as the Supreme Court, the Constitutional Court, the House of Representatives, the Regional Representative Council, and the Audit Board. Since Judicial Commission is not a state institution carrying out the function of state power directly, the Judicial Commission is not a judicial, executive, or legislative institution. This commission only functions to uphold the honor, the high status and the behavior of judges as law enforcement officials and institutions that carry out the functions of judicial power. ${ }^{11}$ In Indonesia, as stated in the 1945 Constitution, Law No. 22 of 2004 and Law No. 18 of 2011, the strategic roles that can be carried out by Judicial Commission is; 1) proposing the appointment of supreme justices - this role is done to avoid the strong interests of the executive or legislative in the recruitment of supreme justices, and 2) safeguarding and upholding the honor, the high status and the behavior of judges - this is done with systematic and intensive external supervision by independent institutions and community towards the judiciary. ${ }^{12}$

This role must be immediately realized by Judicial Commission in order to improve the implementation of law enforcement in Indonesia. The number of alleged bribery cases involving judges in the Supreme Court has decreased public trust against this institution. The spread of pessimism and public distrust against law enforcement institutions in Indonesia has lasted for a long time. The indication of case trading by law enforcement officials occurred from the first court to the appeal level in various regions. The widespread bribery cases involving judges has further strengthened the negative image of the court as well as has shown the difficulty to find legal justice that is truly clean and objective in judicial system in Indonesia. ${ }^{13}$ Article 24A paragraph (3) of the 1945 Constitution states candidates for supreme justices are proposed by the Judicial Commission for approval to the DPR and

10 Ibid., p. 189. Lihat juga Jimly Asshiddiqie, 2009, Komentar Atas UUD Tahun 1945, Jakarta : Sinar Grafika, p. 100.

$11 \quad$ Ibid.

12 Sirajudin and Zulkarnain, 2006, Komisi Yudisial..., Op Cit, p. 72-73.

13 Ibid., p. 73. 
subsequently installed as supreme justices by the President. Article 24B of the 1945 Constitution describes that:

(1) The Judicial Commission shall be independent in nature and have the competence to make proposals for the appointment of supreme justices as well as other competences within the framework of safeguarding and upholding the honor, the high status and the behavior of judges.

(2) The members of the Judicial Commission must have knowledge and experience in matters of law and an integrity and personality beyond reproach.

(3) The members of the Judicial Commission are to be appointed and dismissed by the President in agreement with the DPR.

(4) The organization, authority, and membership of the Judicial Commission shall be regulated by law.

Of these duties and authorities, it is clear that the Judicial Commission is auxiliary to the implementation of the tasks of judicial power which is ultimately held by the Supreme Court. The tasks relate to the recruitment of supreme justices and the coaching of judges in an effort to safeguard and uphold the honor, the high status and the behavior of judges. The honor, the high status and the behavior of judges are very important to be safeguarded and upheld so that the judicial system in Indonesia as a whole can be trusted by the community. Democracy will not grow and develop without being controlled by the rule of law which is based on a credible judicial power system. To safeguard and build confidence, a separate institution is needed to carry out this noble effort. ${ }^{14}$

The Judicial Commission is not intended as a rival institution nor is it in a position against the judicial institutions. The Judicial Commission is not a judicial supervisory agency or a judicial power supervisory agency. The Judicial Commission is also not established with the purpose to eradicate judicial mafia since judicial mafia is included in the category of criminal act that must be eradicated by law enforcement officials. Whereas, the Judicial Commission is not an agency of law enforcement, but an agency that enforces ethical codes and behaviors deviation of judges (deviation against legal norms). The supervision carried out by the Judicial Commission is very important to encourage judges to improve themselves and to avoid improper behavior. If there is an indication of violation, the Judicial Commission can proceed to law enforcement officials for further legal proceedings. ${ }^{15}$

By the existence of the Judicial Commission, it is expected that the system of rule of ethics can be developed effectively, in addition to the system of rule of law that needs to be continuously strengthened. If the implementation of the duties of the Judicial Commission in safeguarding and upholding the honor, the high status and the behavior of judges can be carried out properly, it will indirectly influence the efforts to build a reliable judiciary which is free from corrupt and collusive practices as well as judicial mafia. Therefore, the successful implementation of the duties of the Judicial Commission itself is important to clean the court of all dirty practices. ${ }^{16}$ One of the reasons for establishing the Judicial Commission is that citizens outside the official structure of the parliamentary body can be involved in the appointment process, performance evaluation and possible dismissal of judges, and safeguarding the honor and the high status of judges. Thus, it is expected that the judicial power independence and the accountability principle of judicial power both in legal and ethical terms can be realized. Therefore, the independent supervisory institution of judges must be formed outside the structure of the Supreme Court. Through the Judicial Commission, it is expected that the community's aspirations will be involved in the process of appointing a Supreme Justice and evaluating work ethics and possible ethical violations committed by judges.

In that context, at first, the existence of the Judicial Commission was also associated with a supervisory function that was external to the judicial power. The existence of the Judicial Commission

\footnotetext{
14 Jimly Asshiddiqie, 2008, Pokok-Pokok Hukum Tata Negara Pasca Reformasi, Jakarta : Bhuana Ilmu Populer, p. 576-577.

$15 \quad$ Ibid., p.577.

$16 \quad$ Ibid., p.577-578.
} 
outside the structure of the Supreme Court is considered important so that the supervision process can be objective in order to develop a clean, effective and efficient judicial system. The implementation and form of supervision carried out by the Judicial Commission may not violate the independence of judicial power. Therefore, the supervisory authority of the Judicial Commission is limited to nonjudicial matters.

Similar to the Constitutional Court, the Judicial Commission is a relatively new constitutional phenomenon so that its presence in an ideal form is still at the formulation level. In Europe, there were 7 (seven) countries that had the Judicial Commission until 1999, including: France, Italy, Spain, Portugal, Ireland, Sweden and Denmark. Meanwhile, throughout the world, out of 197 countries of UN members, there are 43 countries - including the 7 European countries, which have Judicial Commission. In 21 of the 43 countries, the Chief of the Supreme Court as Ex-officio becomes the Chief of the Judicial Commission. Meanwhile, in other countries (including Indonesia), the provisions regarding the organizational structure of the Judicial Commission are not regulated in the constitution. ${ }^{17}$

The Judicial Commission of the Republic of Indonesia consists of a chairman, a deputy chairman who concurrently serves as a member, and five members consisting of former judge, legal practitioner, legal academic, and community member. ${ }^{18}$ They are appointed and dismissed by the President with the approval of the DPR for a term of 5 years and after that can be re-elected for one term. ${ }^{19}$ The following requirements must be met if someone wants to be a member of the Judicial Commission: (1) Indonesian citizens; (2) devoted to God Almighty; (3) the lowest age is 40 (forty) years and the highest is 68 (sixty eight) years; (4) having a minimum 15 (fifteen) years of experience in legal field; (5) possessing impeccable integrity and personality; (6) physically and mentally healthy; (7) have never been sentenced for committing a crime; and (8) reporting a list of assets. ${ }^{20}$

In order to carry out their functions honestly and optimally, the members of the Judicial Commission are prohibited from concurrently serving as: (1) state official or state organizer according to legislations; (2) judge; (3) advocate; (4) notary and/or Land Deed Officer (PPAT); (5) entrepreneurs, manager or employees of state-owned enterprises (BUMN) or private business entities; (6) civil servants; or (7) political party management. ${ }^{21}$ The process of respectful dismissal to the membership of the Judicial Commission from his position is carried out by the President at the suggestion of the Judicial Commission if: (1) dies; (2) own request; (3) physically and mentally sick continuously; or (4) the term of office ends. Meanwhile, the process of disrespectful dismissal is done by the President in agreement with the DPR at the suggestion of the Judicial Commission because: (1) violating the oath of office; (2) sentenced to criminal for committing a crime based on a court decision that has obtained permanent legal force; (3) committing disgraceful deeds; (4) continually neglecting their obligations; or

17 Djohansjah, 2008, Reformasi Mahkamah Agung Menuju Independensi Kekuasaan Kehakiman, Bekasi : Kasaint Blanc, 2008, p. 115-116.

18 Indonesia, Undang-Undang Nomor 18 Tahun 2011 Tentang Perubahan Atas Undang-Undang Nomor 22 Tahun 2004 Tentang Komisi Yudisial, Lembaran Negara Republik Indonesia (LNRI) Tahun 2011 Nomor 106 dan Tambahan Lembaran Negara (TLN) Nomor 5250, Pasal 6.

19 Indonesia, Undang-Undang Nomor 18 Tahun 2011 Tentang Perubahan Atas Undang-Undang Nomor 22 Tahun 2004 Tentang Komisi Yudisial, Lembaran Negara Republik Indonesia (LNRI) Tahun 2011 Nomor 106 dan Tambahan Lembaran Negara (TLN) Nomor 5250, Pasal 29.

20 Indonesia, Undang-Undang Nomor 18 Tahun 2011 Tentang Perubahan Atas Undang-Undang Nomor 22 Tahun 2004 Tentang Komisi Yudisial, Lembaran Negara Republik Indonesia (LNRI) Tahun 2011 Nomor 106 dan Tambahan Lembaran Negara (TLN) Nomor 5250, Pasal 26.

21 Indonesia, Undang-Undang Nomor 22 Tahun 2004Tentang Komisi Yudisial, Lembaran Negara Republik Indonesia (LNRI) Tahun 2004 Nomor 89 dan Tambahan Lembaran Negara (TLN) Nomor 4415, Pasal 31. 
(5) violating the prohibition of dual position based on legislations. ${ }^{22}$ In carrying out its duties and functions, the Judicial Commission is assisted by the Secretariat General led by a Secretary General who is a civil servant. The Secretariat General of the Judicial Commission has the task of providing operational administrative and technical support to the Judicial Commission. ${ }^{23}$

\section{Duties and Authorities of the Judicial Commission of the Republic of Indonesia}

The clarity of the legal structure of the Judicial Commission in the constitutional structure, especially in judicial power, is stated in Article 24B paragraph (1) of the 1945 Constitution that: "The Judicial Commission shall be independent in nature and have the competence to make proposals for the appointment of supreme justices as well as other competences within the framework of safeguarding and upholding the honor, the high status and the behavior of judges". Operationally, the provisions of Article 24B paragraph (1) of the 1945 Constitution are described in Article 13 of Law No. 22 of 2004 concerning Judicial Commission (hereinafter referred to as UUKY) that in its position as a judicial institution, the Judicial Commission is given authorities to:

(1) Propose the appointment of supreme justices to the DPR.

(2) Safeguard and uphold the honor, the high status and the behavior of judges. ${ }^{24}$

Based on these provisions, the Judicial Commission has at least two main authorities, namely: 1) proposing the appointment of supreme justices and 2) safeguarding and upholding the honor, the high status and the behavior of judges. From the first authority, it can be said that KY is a state institution that has the authority to serve. Thus, KY can be called a state institution providing services (auxiliary body). However, based on the second authority, the Judicial Commission is not an auxiliary body. It means that KY is the main state institution. Hence, according to Sri Soemantri, there are two characteristics of state institutions in the Judicial Commission. ${ }^{25}$ The formulation of Article 24B of the 1945 Constitution after the amendment to Article 13 of Law No. 22 of 2004 concerning Judicial Commission is substantially considered to weaken the position of the Judicial Commission and is not in accordance with the initial idea of establishing a Judicial Commission. The establishment of a Judicial Commission is regulated in Article 24B of the 1945 Constitution that: 1) The Judicial Commission shall be independent in nature and have the competence to make proposals for the appointment of supreme justices as well as other competences within the framework of safeguarding and upholding the honor, the high status and the behavior of judges; 2) The members of the Judicial Commission must have knowledge and experience in matters of law and an integrity and personality beyond reproach, 3) The members of the Judicial Commission are to be appointed and dismissed by the President in agreement with the DPR, and 4) The organization, authority, and membership of the Judicial Commission shall be regulated by law.

Thus, in carrying out its duties and authorities, the Judicial Commission also works with the Supreme Court and the Constitutional Court, not with the government or the House of Representatives. In carrying out its duties and authorities, the Judicial Commission must be closer to the Supreme Court and the Constitutional Court, not with the government or parliament. More specifically, the Judicial

22 Indonesia, Undang - Undang Nomor 22 Tahun 2004 Tentang Komisi Yudisial, Lembaran Negara Republik Indonesia (LNRI) Tahun 2004 Nomor 89 dan Tambahan Lembaran Negara (TLN) Nomor 4415, Pasal 32 dan 33 Ayat (1). Indonesia, Undang-Undang Nomor 18 Tahun 2011 Tentang Perubahan Atas Undang-Undang Nomor 22 Tahun 2004 Komisi Yudisial, Lembaran Negara Republik Indonesia (LNRI) Tahun 2011 Nomor 106 dan Tambahan Lembaran Negara (TLN) Nomor 5250, Pasal 12 Ayat (1). Indonesia, Undang-Undang Nomor 18 Tahun 2011 Tentang Perubahan Atas Undang-Undang Nomor 22 Tahun 2004 Tentang Komisi Yudisial, Lembaran Negara Republik Indonesia (LNRI) Tahun 2011 Nomor 106 dan Tambahan Lembaran Negara (TLN) Nomor 5250, Pasal 12. 
Commission must take distance so that the Judicial Commission does not become a political tool for politicians, both those who occupy executive or legislative positions, the government or the House of Representatives to control and intervene in the independence of the judicial power. ${ }^{26}$

On the contrary, based on Article 2 of Law No. 22 of 2004 concerning Judicial Commission, the Judicial Commission is a state institution that is independent and is free from interference of other powers in carrying out its authority. Thus, the Judicial Commission as an independent institution must be free from the intervention and influence of other state institutions. However, being independent does not mean that the Judicial Commission is not required to be accountable by the Law.

According to the provisions of Chapter III Article 13 of Law No. 18 of 2011 concerning Amendments to Law No. 22 of 2004 concerning Judicial Commission, the Judicial Commission has the authority to (a) propose the appointment of supreme justices and (b) safeguard and uphold the honor, the high status and the behavior of judges. Furthermore, as stated in Article 14 of Law No. 22 of 2004, in carrying out its authority as referred to Article 13 letter a, the Judicial Commission has the duties to:

(1) Register candidates for Supreme Justices;

(2) Select candidates for Supreme Justices;

(3) Determine candidates for Supreme Justices; and

(4) Propose candidates for Supreme Justices to the DPR.

Article 14 Paragraph (1) of Law No. 22 of 2004 concerning Judicial Commission states: (i) In the event that the term of office of the Supreme Justices end, the Supreme Court submits the list of names of the Supreme Justices to the Judicial Commission within a period of at least 6 (six) months before the term of office ends; and (ii) the implementation of the task referred to Paragraph (1) is conducted within a period of 6 (six) months at the latest since the Judicial Commission receives notification from the Supreme Court regarding the vacancy of the Supreme Justices. Within a maximum period of 15 (fifteen) days from receiving notification regarding the vacancy of the Supreme Justices, the Judicial Commission announced the registration of the candidates for supreme justices for 15 (fifteen) consecutive days. The Supreme Court, the government and the community can propose candidates for Supreme Justices to the Judicial Commission. The proposal of candidates as referred to paragraph (2) shall be made in the announcement of registration of candidates for supreme justices as referred to paragraph (1). In Article 20 of Law No. 18 of 2011 Regarding Amendments to Law No. 22 of 2004 concerning Judicial Commission, it is stated:

(1) In terms of safeguarding and upholding the honor, the high status and the behavior of judges, the Judicial Commission has the duties to:

1. Supervise the behavior of judges;

2. Receive report from the community relating to violations of the Code of Ethics and/or the Code of Conduct of Judges;

3. Verify, clarify and investigate the report of alleged violations of the Code of Ethics and/or the Code of Conduct of Judges;

4. Decide whether or not the report of alleged violation of the Code of Ethics and/or the Code of Conduct of Judges is correct; and

5. Take legal steps and/or other steps against individuals, groups, or legal entities that demean the honor and the high status of judges.

(2) In addition to the duties as referred to paragraph (1), the Judicial Commission also has the duty to increase the capacity and welfare of judges.

(3) In order to safeguard and uphold the honor, the high status and the behavior of judges as referred to paragraph (1) letter a, the Judicial Commission may request assistance from law enforcement

26 Jimly Asshiddiqie, 2005, Perkembangan dan Konsolidasi Lembaga Negara...Op. Cit., p.189-190. 
officials to conduct wiretapping and record conversations in the event of a violation of the Code of Ethics and/or the Code of Conduct of Judges.

(4) Law enforcement officials are obliged to follow up on the request of the Judicial Commission as referred to paragraph (3).

\section{B. Position and Authority of the Judicial Commission in European Countries}

One of the reasons of the establishment of the Judicial Commission in European countries is to revive public trust against judiciary. Many reasons and motives exist to establish Judicial Commission in European countries. Yet, in some European countries, Judicial Commission is established with the aim of developing and realizing efficient judiciary. Judging from the historical background of the Judicial Commission in the European Union, the establishment of the Judicial Commission was inspired by the emergence of a wave of democracy in Eastern Europe which demands a judicial process that can be trusted by the public. The initial idea of establishing a Judicial Commission in Europe was to connect the interests of the government and the interests of the judiciary as well as to guarantee judicial independence. In that context, the main roles of the Judicial Commission in the European Union are; 1) to guarantee the judicial system, 2) to propose professional candidates for judges, 3) to provide quality education to judges, 4) to test the competence of judges, 5) to uphold the code of ethics of judges, 6) to develop public networks, and 7) to take over the judicial management function from the government. These roles are described by various advanced authorities concerning disciplinary action, determination of judges' career, judges' selection, judges' education, and general policies regarding public services available in judiciary, such as budget facilities, official housing, and technological upgrading.

The Judicial Commission in Northern Europe has responsibility and competence in the area of technical policy, namely policy making in judicial field. The first function is related to how to streamline the judicial budget and formulate SOP related to Public Relations. The second function is the managerial function carried out on the judiciary which includes housing for judges, courtrooms, and public information. Meanwhile, the Judicial Commission in Southern Europe has the authority in determining careers, recruitment, education, periodic training, rotation, mutation, and promotion of judges as well as enforcement of discipline (code of ethics). ${ }^{27}$ As a comparison, the position, duties and authority of the Judicial Commission in northern Europe, namely the Netherlands, will be explained.

\section{Judicial Power and Background of the Establishment of the Judicial Commission in the Netherlands}

Judicial power in the Dutch constitutional system is described as a judicial institution that has independence as regulated in the Dutch constitution (ground wet) ${ }^{28}$ The Dutch Constitution states that members of the judiciary (judges) and the Procerure General in the Supreme Court are appointed for a lifetime by the government. Members of the judiciary can only be suspended temporarily or fully dismissed by the court specified in the Law. Thus, constitutional guarantees for judicial independence are only valid for individual members of the judiciary.

In a functional sense, the judicial independence in the Netherlands is guaranteed at all levels. However, the Dutch system does not recognize the terms absolute independence and absolute separation of powers. The separation of powers in the Dutch system has the characteristics of checks and balances where the most important state powers work together in certain fields, influence each other and (as a result of that) control each other. Therefore, to some extent, the judiciary depends on

Wim Voermans, "Indonesia Councils for Judiciary...Op. Cit., p.135-136.

Lihat Pasal 117 Konstitusi atau Grondwet (Gw) Belanda 
other state powers. ${ }^{29}$ In an operational context, the judiciary in the Netherlands is partially dependent on the government, namely the Minister of Justice who has a managerial responsibility for the budget and acts as an agency responsible for the supporting staff of the judiciary. The government is also involved in appointing members of judiciary and monitoring various non-intrinsic data from the judiciary.

Since 1992, the judiciary in the Netherlands has made fundamental changes. This change was specifically made to create conditions that can improve and maintain the quality and services of the judiciary and to create a balance in the structure of the judiciary. ${ }^{30}$ In 1977, the Dutch Minister of Justice and Security and the Dutch Lower House established a commission called the Leemhuis Commission to provide input on matters relating to the management and quality of future judicial institutions. ${ }^{31}$ On January 1998, the Leemhuis Commission issued its final report entitled 'Jurisdiction with the Time'. The report contains an input to the Minister of Justice to continue the establishment of a Judicial Commission. The Judicial Commission is an intermediary organization between politics and administrators who are politically responsible for the judiciary (the Minister of Justice). The Judicial Commission is like a double-edged sword where in one hand, it promotes judicial independence in an organizational sense, on the other hand, it broadens the responsibility and self-responsibility of the judiciary, especially in the fields of administration, management and budget. ${ }^{32}$

The establishment of the Judicial Commission is part of a wider revised operational framework of the Dutch judiciary. The goal is essentially practical, namely a Judicial Commission can help expand the managerial responsibility of the judiciary. In line with the proposal of the implementation of integral management, the presence of the Judicial Commission is also expected to improve the efficiency and the independence of the judiciary. The Judicial Commission has a number of authorities in policy making (including external affairs, public services, judicial collaboration, personnel management and appointment of candidates for judges, and provide advice to the Minister of Justice for quality improvement) and duties related to management (including housing and security, automation, organizational administration, and provision of administrative information). ${ }^{33}$ Considering the need for the judiciary to focus on their judicial duties and the inefficiency of budget management by the judiciary, in 2002, an integrated judicial management system and the establishment of a Judicial Commission in the Dutch judicial system is realized through a judicial system reorganization program in the Netherlands. ${ }^{34}$ The Dutch Judicial Commission is known by the name Raad Voor de Rechtspraak or the Netherlands Council for the Judiciary (NCJ). The name is regulated in the Judicial Act 1827. NCJ was officially established on January 1, 2011 as an independent institution that has the main role to overcome several problems faced by the Dutch judicial system, including the budget. NCJ has 4 members proposed by the Ministry of Law and approved by the Kingdom of the Netherlands with a term of 6 years and can be extended for 3 years. ${ }^{35}$

\section{Duties and Authorities of the Netherlands Council for the Judiciary}

The Netherlands Council for the Judiciary carries out a number of policy-making tasks and other tasks related to management and budget. The duties and authorities of the NCJ are; a) Policy making (including external affairs, public services, judicial collaboration, personnel management, judges

29 Wim Voermans, 2010, Komisi Yudisial Di Beberapa Negara Uni Eropa,Diterjemahkan oleh Adi Nugroho dan M. Zaki Hussein,Jakarta : Lembaga Kajian dan Advokasi Untuk Independensi Peradilan (LeIP),p.121-122.

Idem., p.124.

Idem., p.126-127.

Idem., p.127.Lihat juga dalam Wim Voermans, "Indonesia Council for Judiciary...Loc. Cit.

Wim Voermans,Komisi Yudisial..., Op.Cit. p. 127.

Komisi Yudisial Republik Indonesia. 2014. Studi Perbandingan Komisi Yudisial Di Beberapa Negara. Jakarta : Sekretariat Jenderal KomisiYudisial RI, p. 88.

Idem., p. 89. 
selection policies, research policies, provides advice to the Department of Justice, and quality policies); b) Authorities related to management (including housing and security, automation, organizational administration, and provision of administrative information); c) Budget policies (budget procedures, budget distribution procedures, and justification of budget expenditures); and d) Other authorities (including corrective or disciplinary authority, proposing candidates for judges, and proposing promotion and placement of judges). ${ }^{36}$

\section{CONCLUSION}

The duties and the authorities of the Judicial Commission are to support the implementation of the tasks of the judicial power which is ultimately held by the Supreme Court. The tasks relate to the recruitment of supreme justices and the coaching of judges in an effort to safeguard and uphold the honor, the high status and the behavior of judges. The honor, the high status and the behavior of judges are very important to be safeguarded and upheld so that the judicary system as a whole can be trusted by the community. Democracy will not grow and develop without being controlled by the rule of law which is based on a credible judicial power system. To safeguard and build confidence, a separate institution is needed to carry out this effort. Judicial Commission has an important position so as structurally, its position is aligned with the Supreme Court and the Constitutional Court. However, it should be noted that, although structurally its position is aligned with the Supreme Court and the Constitutional Court, but functionally, its role is auxiliary to the judicial power institutions. Although the function of Judicial Commission is related to judicial power, but Judicial Commission is not an agent of judicial power.

The Judicial Commission is not a code of law enforcement agency, but a code of ethics enforcement agency because this commission only deals with the honor, the high status and the behavior of judges, not with judicial institutions or judicial power institutions. This system is quite different from the Judicial Commission in Europe, especially in Northern Europe. The Judicial Commission in Northern Europe, as represented by the Netherlands, has responsibility and competence in the area of technical policy, policy making in the judiciary field, authority relating to management and budget policy, and other authorities, such as corrective or disciplinary authority, authority for proposing candidates for judges in appointment process, etc.

\section{SUGGESTION}

The Judicial Commission in Indonesia needs to adopt or imitate the Netherlands Council for the Judiciary and adapt it to the constitutional system in Indonesia. The Netherlands Council for the Judiciary has the authority in managing organization, budget and administration as well as in conducting promotions, transfers, and recruitment as well as imposing sanctions on judges. Thus, the Supreme Court only focuses on carrying out judicial functions and does not deal with administrative and judicial organization matters. Thus, the Supreme Court is expected to become a professional institution in enforcing law and justice.

\section{REFERENCES}

\section{Books}

Asshiddiqie, Jimly. 2009. Komentar Atas UUD Tahun 1945. Jakarta : Sinar Grafika. 2005. Perkembangan dan Konsolidasi Lembaga Negara Pasca Reformasi. Jakarta : Konpress MKRI.

\footnotetext{
36 Lintong O. Siahaan, "Komisi Yudisial Sebagai Lembaga Kontrol Hakim”, Jurnal Hukum dan
} Pembangunan, Vol. 35, No. 4, 2005. p. 421. 
Populer.

Djohansjah. 2008. Reformasi Mahkamah Agung Menuju Independensi Kekuasaan Kehakiman. Bekasi : Kasaint Blanc.

Komisi Yudisial Republik Indonesia. 2014. Studi Perbandingan Komisi Yudisial Di Beberapa Negara. Jakarta : Sekretariat Jenderal Komisi Yudisial RI.

Sirajuddin dan Zulkarnain. 2006. Komisi Yudisial dan Eksaminasi Publik. Bandung : Citra Aditya Bakti.

Suparto.2017. Dinamika Hubungan Antara Komisi Yudisial Dengan Mahkamah Agung Republik Indonesia. Jakarta : Bina Karya.

Thohari, A. Ahsin. 2004. Komisi Yudisial dan Reformasi Peradilan. Jakarta : Lembaga Studi dan Advokasi Masyarakat (ELSAM).

Tutik, T. Triwulan.2007. Eksistensi, Kedudukan dan Wewenang Komisi Yudisial ; Sebagai Lembaga Negara Dalam Sistem Ketatanegaraan RI Pasca Amandemen UUD 1945. Jakarta : Prestasi Pustaka Publisher.

1945. Jakarta : Cerdas Pustaka Publisher.

Voermans, Wim. 2002. Komisi Yudisial Di Beberapa Negara Uni Eropa, Diterjemahkan oleh Adi Nugroho dan M. Zaki Hussein. Jakarta : Lembaga Kajian dan Advokasi Untuk Independensi Peradilan (LeIP).

\section{Journals, Papers}

Abustan. "Relasi Lembaga Negara dalam Perspektif Undang-Undang Dasar Negara Republik Indonesia 1945", Jurnal Unifikasi, Vol. 4, No. 2, Juli 2017. P.55-63.

Erniyanti. "Eksistensi Kewenangan Komisi Yudisial dalam Pengawasan Hakim Menurut UndangUndang Dasar Negara Republik Indonesia Tahun 1945”, Jurnal Samudra Keadilan, Vol. 10, No.2, 2015. P. 241-254.

Nurhayati, Nunik. “ Eksistensi Kewenangan Komisi Yudisial Republik Indonesia dalam UndangUndang Dasar Republik Indonesia 1945”, Jurnal Law and Justice, Vol. I, No. 1, 2016. P.9-15.

O. Siahaan, Lintong. "Komisi Yudisial Sebagai Lembaga Kontrol Hakim", Jurnal Hukum dan Pembangunan, Vol. 35, No. 4, 2005. P. 408-432

Suparto."Kedudukan dan Kewenangan Komisi Yudisial Republik Indonesia dan Perbandingannya Dengan Komisi Yudisial Di Beberapa Negara Eropa”, Jurnal Hukum dan Pembangunan, Vol. 47, No. 4, 2017. P. 497-513

Sutiyoso, Bambang. “Penguatan Peran Komisi Yudisial dalam Penegakan Hukum di Indonesia”, Jurnal IusQuia IusTum, Vol. 18, No. 2, 2011. P.266-284.

Thohari, A. Ahsin. "Kedudukan Komisi - Komisi Negara Dalam Struktur Ketatanegaraan Indonesia”, Jurnal Hukum JENTERA, Edisi 12-Tahun III, 2006. P. 35-52.

Voermans, Wim. "Indonesia Councils for Judiciary, Seminar of Comparative of Judicial Commissions" Makalah dalam Seminar Peran Komisi Yudisial Di Era Transisi Menuju Demokrasi. Komisi Yudisial RI. Jakarta 5 Juli 2004.

\section{Legislations}

Indonesia, Undang-Undang Dasar Negara Republik Indonesia Tahun 1945

Indonesia, Undang - Undang Nomor 22 Tahun 2004 Tentang Tentang Komisi Yudisial, Lembaran Negara Republik Indonesia (LNRI) Tahun 2004 Nomor 89, dan Tambahan Lembaran Negara (TLN) Nomor 4415 
Indonesia, Undang - Undang Nomor 18 Tahun 2011 Tentang Perubahan Atas Undang-Undang Nomor 22 Tahun 2004 Tentang Komisi Yudisial, Lembaran Negara Republik Indonesia (LNRI) Tahun 2011 Nomor 106, dan Tambahan Lembaran Negara (TLN) Nomor 5250

Konstitusi (Ground Wet) Belanda 